\title{
陸面水文モデルに対する降水時間スケールの グローバル影響評価
}

\author{
ANALYSES OF GLOBAL DEPENDENCE OF SIMULATED LAND SURFACE \\ HYDROLOGICAL BUDGET ON TEMPORAL SCALE OF PRECIPITATION
}

\author{
平林 由希子 ${ }^{1} \cdot y_{1}$ 信次郎 ${ }^{2} \cdot$ 沖 $^{\text {大幹 }^{3}} \cdot$ 虫明 功臣 ${ }^{4}$ \\ Yukiko HIRABAYASHI, Shinjiro KANAE,Taikan OKI, and Katumi MUSIAKE

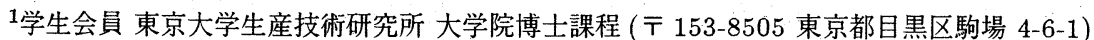 \\ 2 正会員 博士 (工学) 東京大学生産技術研究所 助手 ( $₹$ 153-8505 東京都目黑区駒場 4-6-1) \\ 3 正会員 博士 (工学) 東京大学生産技術研究所 助教授 ( $\bar{T} 153-8505$ 東京都目黑区駒場 4-6-1) \\ 4正会員 工学博士 東京大学生産技術研究所 教授 (T 153-8505 東京都目黒区駒場 4-6-1)
}

\begin{abstract}
Sensitivity of Land Surface Model (LSM), which is designed to simulate water and energy on large scale, to the temporal precipitation resolution is examined. The results of two sets of off-line experiments by a LSM are investigated. The first set of the experiments is global $1^{\circ} \times 1^{\circ}$ simulation in 1987 , which is driven by the same atmospheric forcings but different precipitation input, varying in temporal scale from high (6-hourly) to low(deca-day or monthly). Low temporal prccipitation is obtained by averaging original 6-hourly precipitation. Original 6-hourly and obtained deca-day averaged or monthly averaged precipitation forcing are provided to the model and the results are compared at each grid pixel. The results show that increases in surface runoff are obtained at most of the grids with the low temporal precipitation, due to large increase in canopy interception. At the place where monthly LAI value is large and monthly precipitation is around $100 \mathrm{~mm} / \mathrm{mon}$, the effects of the temporal scale of precipitation tend to be the largest. Another set of experiments is also $1^{\circ} \times 1^{\circ}$ off-line simulation at one grid pixel using the accumulation of the observed precipitation. Three downscaling schemes for retrieving daily precipitation from the monthly value are compared in terms of water balance calculated in the LSM. Both the number of days and intensity are shown to be important for the hydrological estimation in LSM. The water balance calculated in the experiment with $\gamma$ distribution method shows fairly well accorded with the experiment using observed daily precipitation, and shows the applicability of the scheme for downscaling of daily precipitation from monthly data.
\end{abstract}

Key Words : LSM, precipitation frequency, global water balance, down scaling

\section{1.はじめに}

モデル開発における深刻な問題として, モデルに与 える入力データの不足が挙げられる. モデルの再現性 も，主に境界值や検証用などのデータの不足によって制 限されることがしばしば生じる. 従って, 現実的にはあ る程度妥協した入力データ,つまりバイアスを含んだ数 值モデルによる再現值や, 時間・空間解像度が粗い入力 デー夕を，適宜補間や再分配などを行い，必要な目的の 為に十分であるという判断を下した上で使用すること となる.

本論文では, 主に世界水資源研究に使用されるよう なグローバルな範囲で地球上の淡水量を算定するモデ ルを対象とし，妥当な水資源量を得るためには，どのよ うな時間スケールの降水デー夕を陸面モデルに与える 必要があるかということに着目し，陸面モデルの降水
の時間スケールに対する感度を明らかすることと，降 水の時間ダウンスケーリング手法の適用性を調べるこ とを目的とする. 具体的には, 温暖化などの気候変動研 究に用いられる大気大循環モデル (General Circulation Model, 以下 GCM) の陸面部分のサブモデルとして開 発された, 水平解像度が数十 $\mathrm{km}$ から数百 $\mathrm{km}$ 程度の陸 面モデル (Land Surface Model, 以下 LSM) を用いて, 算定される水文量の入力降水量デー夕に対する 2 種類 の感度実験を行う.1つ目の実験では, まず,グローバ ルに大気データの整備された ISLSCP-I デー夕を用い て, 6 時間降水量, 旬平均降水量, 月平均降水量の 3 ケ一 スについての LSM の水文算定量を比較し, 降水の時間 解像度に対する感度が高い地域を抽出する。次に, 2 つ 目の感度実験では, 前の実験において降水の時間解像度 に対する感度が高かった日本の千葉県付近の $1^{\circ} \times 1^{\circ}$ グ 
リッドにおいて, 月降水量から日降水量を求めるダウン スケーリング手法としての $\gamma$ 法の妥当性の検証を行う.

\section{2. グローバル LSM に与える降水データの 時間解像度}

陸面水文モデルで水文量を算定するためには, 土壤 や土地被覆分布などの境界值と, 大気から地面へ受け渡 しされる大気外力を与える必要がある. 大気外力は太 陽から地表面への下向き放射エネルギー, 風速, 気温な どいくつかあるが, その中でも降水量は陸面水文量の算 定を行う際の重要な入力の一つである.しかしながら， 現在グローバルな空間を網羅し，かつ継続的に得ること のできる信頼できる降水量の時間解像度は, 月平均まで である。

グローバルに得られる降水量デー夕は, 観測值, GCM によるモデル算定値，または再解析と呼ばれる過去の データを GCM によって時間空間方向に同化したプ ロダクトの 3 つに分けられる. 観測值の例としては, GPCC(Global Precipitation Climatology Center) に 代表される雨量計観測網から集積されたグリッドデー 夕や, 赤外及びマイクロ波散乱計及びマイクロ波放射計 などの衛星によるもの，それらの混合などがあげられ， 過去約 20 年間までに関して集積・整備されている.し かしながら，これらのデータセットは, 近年 GPCP 等が 1997 年〜現在までの $1^{\circ} \times 1^{\circ}$ 日降水量を作成している以 外は，ほほ全て月平均である1).

一方，世界のいくつかの機関において, GCM のモデ ル出力值や, GCM を利用して過去の観測デー夕を時間 空間の 4 次元方向に同化した長期再解析によるグロー バルな降水データが作成されている。これら数值気候 モデルによる降水量は, 前者の観測値と比較して, 温暖 化予測を含めた長期間のグローバルデータセットが得 られるという利点がある.しかし，用いる GCM のシス テムエラーがあることや, 広域の平均場を再現すること を目的とした GCM の降水量 などでは, 月単位以下の 時間スケールにおける信頼性が小さい場合があること が挙げられる. 例えば, Prudhomme ら²)は，イギリス 気象局の GCM である HadCM2 の温暖化実験による 日降水の頻度分布が平坦で局所的な変動が低いので, 温 暖化による洪水頻度解析を行う際の水文モデルへの入 カデータとしては GCM の温暖化実験の值をそのまま 使うことはできないことを指摘している. Prudhomme らはまた, HadCM2 の温暖化実験による月平均降水量 と現在の月降水量との差分を, 将来の降水パターンによ る異なる 3 種類の日降水シナリオに従って現在の降水 デー夕に分配して解析を行った，その結果, 洪水ピーク の再帰期間は日降水のシナリオによって大きく変化す
ることが示され, GCM における日降水の再現性の重要 性及び, 適切な降水の時間的ダウンスケーリングの手法 の開発が重要であることが提唱された。

温暖化予測など $\mathrm{GCM}$ の出力値を使用するときに限 らず，限られた時間スケールの降水しか得られない場合， 例えば月降水量しか得られない場所・時代について, 水 文量をLSM によって算定する時には，LSM に対する 降水時間スケールの応答を把握したうえで, 必要な目的 に応じた時間スケールの降水データをダウンスケーリ ング手法によって作成する必要がある。

このような観点から LSM の降水時間スケールに対 する応答を調べた研究としては, 佐藤ら ${ }^{3)}$ が挙げられ る. 佐藤らは, $\mathrm{SiB}$ モデル4)5)に札幌官区気象台によって 作成された日本北部の大気外力データの時間観測値を 与え，放射と降水の時間解像度に対するモデルの水収支 計算の感度を調べた。一時間デー夕を外力として与えた 場合と，もとの一洔間毎のア゙ータを平均することにより て作成した粗い時間解像度の外力を与えた場合を比較 した結果, 放射デー夕の時間解像度に対しては感度がほ とんど無かったのに対し，降水に関しては，長い時間平 均を取るほど, 植生による遮断蒸発が増加するため, 時 間解像度への感度が非常に大きいことが示された。

本論文では佐藤らの研究を全球範囲に拡大し, どの ような地域・気候条件において LSM が降水の時間解像 度に対する感度が高いかを明らかにする $(3,4$ 節). 続 いて, 降水の時間解像度に対する感度が高かった地域に おいて, LSM の感度という観点から, 簡便でグローバ ルに適用可能なダウンスケーリング手法 (ここでは $\gamma$ 法) の妥当性の検証を示す (5 節).

\section{3. 使用したデータ及びモデル}

\section{(1) 陸面モデル}

本研究では, 国立環境研究所と東京大学気候システム センターが共同で開発した陸面モデルである MATSIRO 6)を使用した. MATSIRO は多層の雪モデルを組み込 み, キャノピーモデルと $\mathrm{SiB}$ 夕イプの光合成モデルから なる植生モデルと, 簡易型 TOPMODEL の流出スキー 厶を有する LSM である. 水平解像度として緯度・経度 $1^{\circ} \times 1^{\circ}$ の格子を用いた. 与えた大気外力の水平解像度 も全て同じである. 積分計算の時間ステップは 6 時間と し, 土層の鉛直解像度は 5 層である. 積分計算をする前 に, 同じ年の值を与え続けるスピンアップを行った. ス ピンアップは 10 年で打ち切り, 実際の実験はその最後 の值を初期值とした 11 年目の計算である. スピンアッ プ最終年の, 土壤水分貯留量の前年との誤差を調べたと ころ, 土層の第一層から順に, 全陸面グリッドに占める 割合が $90.4,96.83,97.22,98.46,98.49 \%$ のグリッドに 
おいて, 誤差が $5 \%$ 以下となることを確認した。土㥽パ ラメータと土地被覆分布は固定とし, 土地被覆に応じた LAI(Leaf Area Index) は, ISLSCP CD-ROM I による データセットから作成した月平均值を与えた。

\section{(2) 大気外カデータ}

陸面モデルに与える大気外力デー夕は, ISLSCP(International Satellite Land Surface Climatology Project) Initiative CD-ROM の 1987-88 年の 2 年間の $1^{\circ} \times 1^{\circ}$ データ7)を用いる. ISLSCP -I とは, 1987 年と 1988 年の 2 年間について、全球 $1^{\circ} \times 1^{\circ}$ の範囲 で陸面のデータセットを作成した国際プロジェクトで ある。

ISLSCP -I によって，現業の気象予報を行うセ ンタ (ECMWF(European Centre for Medium-Range Weather Forecasts) 及び NCEP(National Centers for Environmental Prediction)) における再解析デー夕, 衛星観測 (NASA/LaRC)，グローバル雨量計観測網 (GPCP) による観測を組み合わせた陸面モデルに与え る大気外力データが整備され，提供された． $2 \mathrm{~m}$ 高度に おける気温及び露点温度, 地表気圧, $10 \mathrm{~m}$ 高度におけ る風速, 長波及び短波放射, 総降水と対流性降水の合計 8 つのプロダクトが 1 日 4 回 $(00,06,12,18 \mathrm{UTC})$ の時 間解像度の外力データとして使える. 放射と降水量以 外は基本的に ECMWF/WCRP $(\mathrm{ECMWF}, 1993)$ のプ ロダクトである．放射は, ECMWF で雲被覆率が過小 評価されることによるシステマティックなバイアスを 除去するため, ECMWF が算定した放射の時間変化を， 月の総量が NASA/LaRC 月平均值と一致するように 嵩上げしたものを用いる．同様に，降水量に関しては， GPCPによる雨量計のみから作成された月降水量デー 夕を, NCEP/NCAR による 6 時間ごとの総降水量と 対流性降水量の予報值を用いて 6 時間ごとに分配され ている。たたし，日降水量の頻度分布は，FGGE(First GARP Global Experiment) 対象期間 (1978 年 12 月 1979 年 11 月) における雨量計を基とした全球 $4^{\circ} \times 5^{\circ}$ の 日降水データの頻度をしきい值として用いて現実に近 くなるような操作が行われている8).

本研究では，ISLSCP-I データのうち，地表面の風 速, 気温, 気圧, 長波及び短波放射は, 6 時間ごとの值を 大気外力として使用した. 地表面の比湿は, 地表面の露 点温度と地表気圧データから求めた。 また, 雲の被覆率 は, ISLSCP-I の月平均データを1ヶ月間一様に与え続 けた。

\section{ISLSCP-I を用いた全球感度解析}

\section{(1) 実験設定}

オリジナルの 6 時間解像度の降水量データから, 異 なった時間解像度を持つ計 3 種類の降水量外力デー夕を 作成し，それらを用いた以下の 3 種類の実験を行なった。

(i) 実験 1: ISLSCP-I の 6 時間データをそのまま与 えたもの

(ii) 実験 2: 実験 1 の旬 (10 日) 平均值を 10 日間与え 続けたもの

(iii) 実験 3: 実験 1 の月平均值を一ヶ月間与え続けた もの

図 1 には，これら 3 種類の外力としての降水量の, 中 国東部における時系列を示す。

[Designed Precipitation]

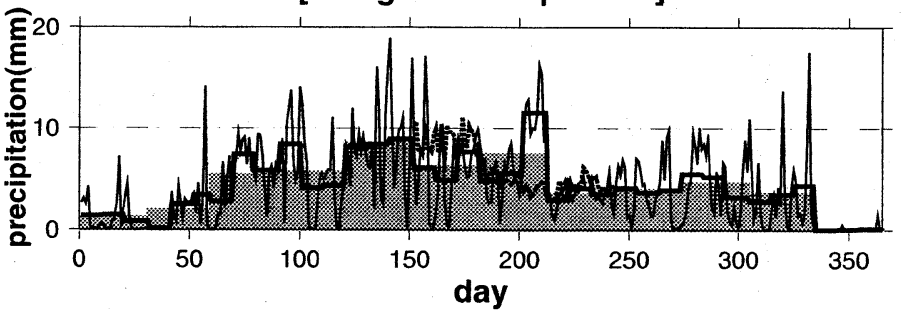

図 1 ISLSCP-I から作成した外力として与える降水量データの 時系列. 中国東部の領域平均值を示す. 細線がオリジナル の 6 時間デー夕, 太線が旬平均, 棒グラフが月平均.

\section{(2) 結果}

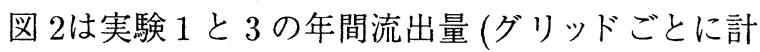
算される流出量) の差を示す. 北米東部, 南米大陸, ア フリカ中南部, インド亜大陸, インドシナ半島, 中国な ど多くの地域において流出の減少が見られる，与えた 降水量の積算值は 3 実験全てにおいて等しいので, 土壤 層への貯水量の変化がほとんど無いと仮定すると, 図 2 に見られるような年流出量の減少は, すなわちその場所 の年蒸発散量の増加と対応すると考えられる.

そこで, 図 2 の矩形に示される4 領域における年蒸 発散量の変化を分析した (図 3 ). 上が実験 2 と実験 1 と の差であり,下が実験 3 と実験 1 との差である. どちら の実験においても, 全ての領域において, 降水の時間解 像度を変えたことによる総蒸発散量の増加が数 $10 \mathrm{~mm}$ 程度みられる。蒸発散量変化の内訳を見てみると, 最も 大きい変化は, 遮断蒸発の増加と蒸散量の減少であるこ とがわかる. 総蒸癹散量の増加は, 蒸散の減少分よりも 遮断蒸発の増加分が多い為である. 遮断蒸発量の増加 は, 平滑化によって平均降水強度が弱くなったことと, 降雨日数が増加したことの 2 つが原因として考えられ る. 蒸散量が減少したのは, 降雨日数の増加によって葉 面に水が付着している時間が長くなりその間の蒸散が 


\section{Change of Runoff (MON minus ORG)}

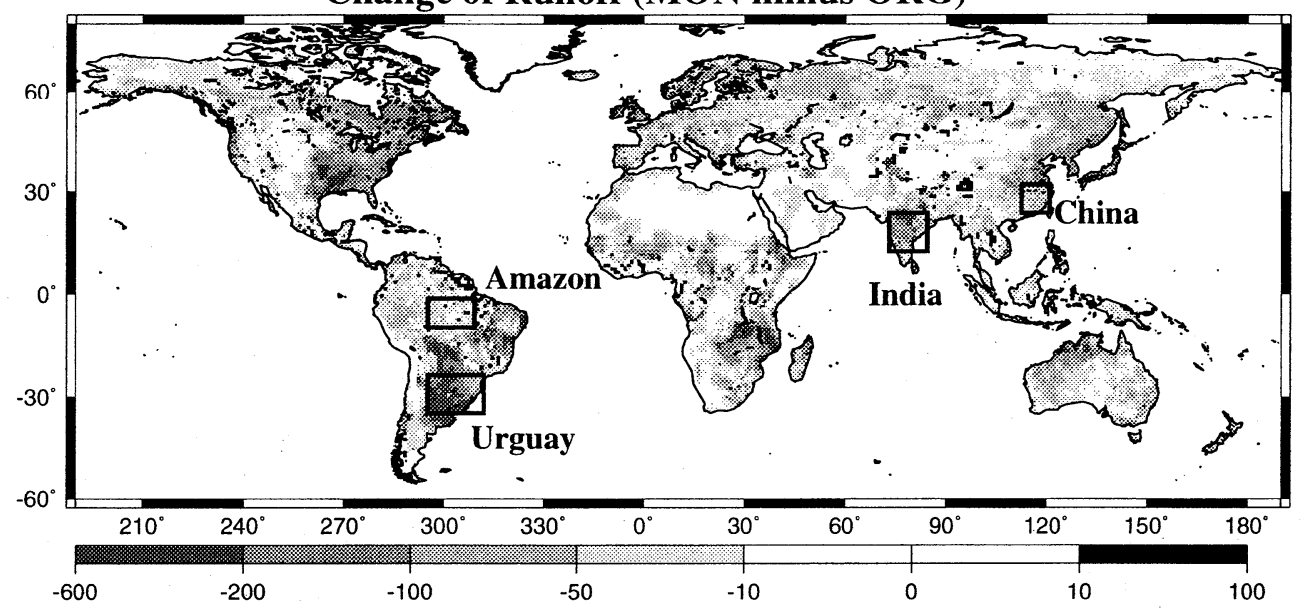

図 2 実験 1 と実験 3 の年流出量の差 (実験 3 - 実験 1 )

抑制されたためである。

以上より，降水の時間解像度が異なる場合には，与 えた降水の数十日間の積算量が等しい場合においても， LSM で得られる陸域水収支が大きく異なるという事が 指摘された. また, 図 3 の上下の図を比較すると, 降水 をより長く平均している実験 $3($ 下) の方が 2 (上) よりも 蒸発散量の変化, 引いては流出量の変化が大きいことが 分かる.
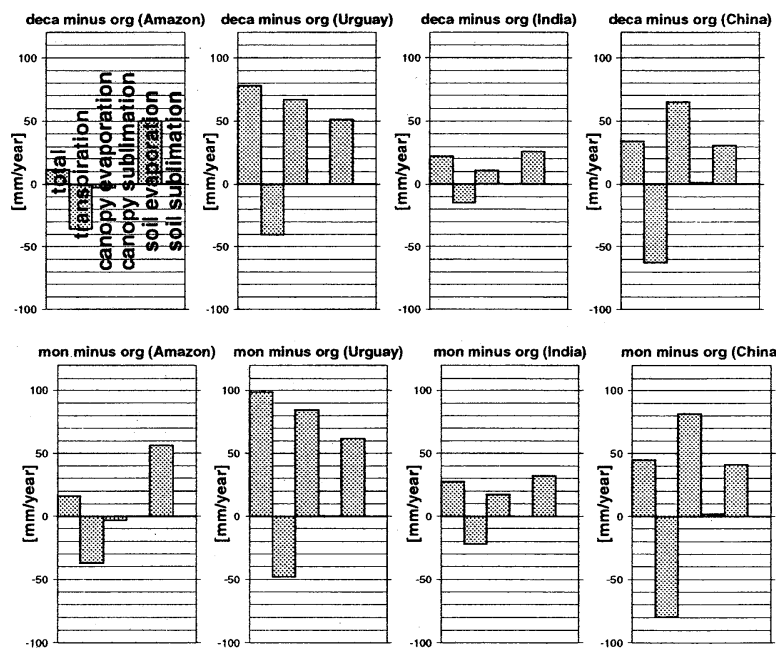

図3 実験 2(上) と $3($ 下) に扔恬る, 実験 1 からの蒸発散量の変 化の内訳: 左加順に全蒸発散, 蒸散, 遮断蒸発, 遮断昇 華, 裸地面蒸発, 裸地面昇華を示す

次に, 実験 3 と実験 1 の差から,どのような地域・気 候で上り降水の時間解像度が陸域水収支算定に与云る 影響が大きいかを調べた。図 4は, 毎月の全ての陸上の グリッドの遮断蒸発の差と月 LAI との関係をプロット したものである. 個々の点は, 12 ケ月それぞれの各 $1^{\circ} \times$ 1 。格子に扔ける值を示す. LAI が低い 1 から 2,3 程 度の場所においては, 遮断蒸発量の差の上限が「LAIの 増加 1 に対して遮断蒸発量の差が $20 \mathrm{~mm}$ 増加」という 割合で変化する。 また, LAI が 3 以上のときは, LAI の 值が大きくなるほど遮断蒸発量の差が少しずつ増加し ていることが, 多くの点において見られる. しかし同時

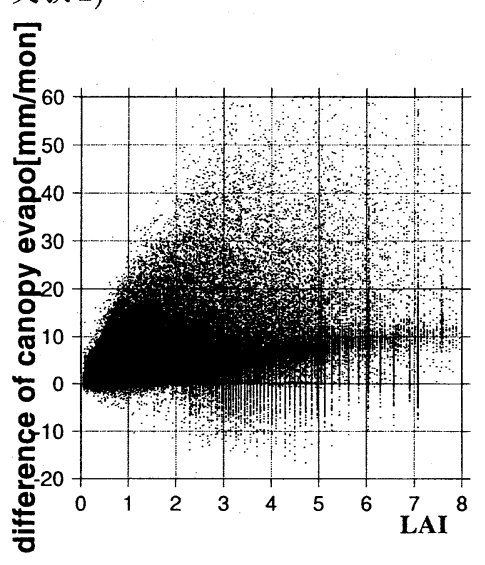

図 4 実験 3 と 1 の遮断蒸発の差と, LAI の関係. それぞれの点は全球のグリッドの各月ごとの 值を示す。

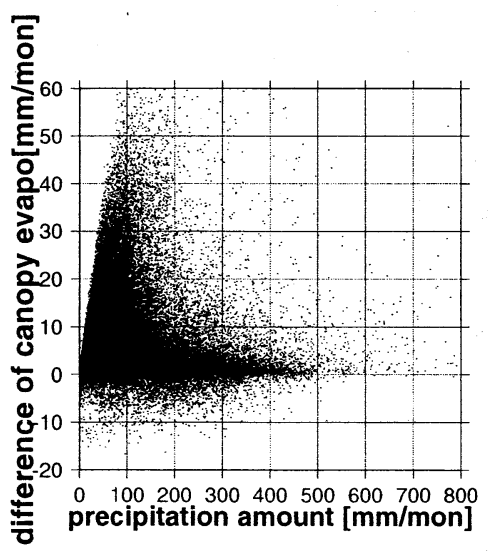

図 5 実験 3 と 1 の遮断蒸発の差と, 月平均降水量 の関係。それぞれの点は全球のグリッドの各 月ごとの值を示す.

に, 図4のプロットは全体として散乱の度合いが大きい.

上記の「LAI が 1 に対して遮断蒸発量の差が $20 \mathrm{~mm}$ の関係の直線が点の分布の上限として見られること」の 原因は, 実験 1 の 6 時間降水では降水が生じていない 時に, 実験 3 では降水が降り続いている為, LAI が補足 
できる LAI × $2(\mathrm{~mm})$ の最大值まで遮断されているこ とを示している.

図 5 は図 4 と同様に, 月降水量を横軸に, 遮断蒸発量 の差を縦軸にプロットしたものである。この図から, 降 水量の時間解像度への感度が高い場所は, 月降水量が $100 \mathrm{~mm} / \mathrm{mon}$ 前後であることがわかる. 月降水量がそ れよりも大きい場合は, 降雨日数がどの実験でも多くな り, 実験間の降雨日数の差が小さくなる為に, 遮断蒸発 量の差が小さくなると解釈できる. 加えて, 葉面が遮断 可能な容量が LAI $\times 2(\mathrm{~mm})$ であるため, 月降水量が $100 \mathrm{~mm} / \mathrm{month}$ よりも大きい場合は, いずれにしろその 許容量を超えてしまいがちであり，降水量の大きさに対 する感度が出なくなっているのであろう。

以上より, 月降水量が $100 \mathrm{~mm}$ 前後の場所では降水 の時間解像度に対する感度が高く, LAI が大きい方がそ のポテンシャルが大きいということが結論づけられる.

\section{LSM の感度からみた日降水配分法の検証}

ここまでは ISLSCP-I データによる 6 時間ごとの降 水量を与え, またそれを平準化することによって感度実 験を行なったが, 実際の応用を考えるとそのような高時 間分解能デー夕はそもそも存在せず, 月雨量をいかに日 雨量, あるいはそれ以下に分解するかが重要になる. 過 去のグローバルな水収支を算定した研究では，もっとも 単純な手法としては一ヶ月の間等しい降水を与え続け ており,何らかの工夫を行なった研究においては, 水収 支の視点からは特に検証もなく, 経験的に $\gamma$ 法が用いら れることが多かった．本研究では，前節までの結果を踏 まえた上で，この過去によく用いられてきた $\gamma$ 法の妥当 性を検討する。

\section{(1) 実験方法}

本節では, アメダスの観測降水量を用いて，MATSIRO の 1 グリッドにおける解析を行う。選定したグ リッドは, 月降水量が $100 \mathrm{~mm} / \mathrm{mon}$ 前後で, かつ LAI が ある程度大きいという, 前の実験で示された降水の時間 解像度に対する感度が高い条件を満たしている千葉県の 房総半島付近である.グリッドの中心位置は $140.5^{\circ} \mathrm{N}$, $35.5^{\circ} \mathrm{E}$ である. 積分期間は，月降水量が $100 \mathrm{~mm} / \mathrm{mon}$ 前後である 1987 年の 5 月 1 日から 8 月 31 日までの 4 ケ 月間とした。

まず,グリッド内に含まれる観測所のうち, 対象期 間にデータのある 16 の観測所において，欠測を除いた 全ての平均值を求めた. 次に, 観測所平均の一ヶ月の積 算量と ISLSCP -I の同じ期間・グリッドの月降水量を 比較し, ISLSCP-I の月降水量に合わせるように, アメ ダスデータに月ごとの一定の比率をかけて嵪上げした。
表 1 千葉県房総半島における感度実験の設定

\begin{tabular}{ccl}
\hline 実験名 & 日降水量の配分方法 & 降雨日数 \\
\hline (a) & 観測値 & 観測值 \\
$(\mathrm{b})$ & 等配分 & 降雨がある月は毎日 \\
$(\mathrm{c})$ & 等配分 & 観測値 \\
$(\mathrm{d})$ & $\gamma$ 分布 & 観測値 \\
\hline
\end{tabular}

ここで月降水量を ISLSCP-I にあわせた理由は, 前節ま での実験結果と比較可能にするためである。

ここでは，月降水量から日降水量を作成するダウン スケーリング手法の適用性を見るために，表 1 にまと めたそれぞれの手法を用いて作成された日降水デー夕 をLSM(MATSIRO) にオフラインで与え, 比較を行う. a) は観測值を用いたものであり，これを最も現実に近 いシミュレーションと考え control 実験とする.b) は全 球感度実験で行ったのと同様の降雨日数を考慮しない 1 ケ月平均の等分配, c) は降水日数は観測值と同じもの を用いるが，月降水量の配分を等配分にするもの, d) は 降水日数は観測值と同じものを用いるが, 月降水量の配 分は $\gamma$ 法で配分する手法である. 以上の (b), (c), (d) の 3 種類の手法を用いて, 月降水観測值から日降水量を求 め，それぞれの手法と実験 (a) との比較検証を行う。今 回の実験では特に降水量の配分手法に着目するため, 降 水日数の推定手法に関しては割愛じ, (c) と (d) では観 測された降水日数を使用している.

グローバルな水収支を求めた既往の研究において， 良く使用されている月降水量を日降水量に配分する手 法は,(d)の $\gamma$ 分布を利用したものである。ここで, $\gamma$ 分 布は次のような式で表わされる.

$$
\begin{array}{r}
f(x)=\frac{\lambda^{\beta} x^{\beta-1} e^{-\lambda x}}{\Gamma(\beta)} \\
x \geq 0, \lambda=\frac{\bar{x}}{\sigma_{x}^{2}}, \beta=\frac{\bar{x}^{2}}{\sigma_{x}^{2}}
\end{array}
$$

$\Gamma:$ ガンマ関数, $\bar{x}$ : 標本の平均值, $\sigma_{x}^{2}$ : 標本分布

$\lambda$ 及び $\beta$ の 2 パラメー夕は，各月ごとの日観測データ から作成した。求めた月ごとの「曲線に囲まれた面積 を降水強度が低い值から積分し, 降水の分布確率 $\times$ 降 水日数の積分面積が 1 を超えるごとに順に降水強度を 求めた。また, 月降水量と $\gamma$ 分布による日降水量の積算 值が合うように, 月最大の降水強度においてずれた分を 調整した.こうして $\gamma$ 分布から求めた日降水は, 乱数を 使って観測值で降水が生じた日にランダムに配置した。

\section{(2) 結果}

図 6 は, 各実験における 4 ケ月間の積算の陸面水収 支を示す. 全ての実験の月降水量は等しく, 4ケ月間の 月積算量は $508.8 \mathrm{~mm}$ である. 観測降水デー夕を入力と 


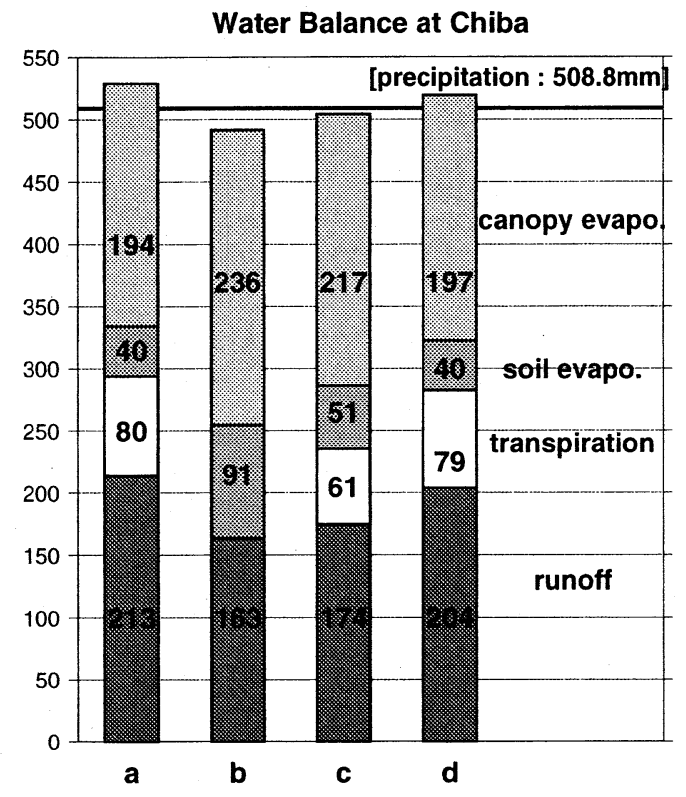

図 6 降水配分手法と LSM の感度

して用いた実験 (a) と比較すると, 残りの 3 実験全てに おいて, 流出量の減少と遮断蒸発量の増加が見られた. 降水を毎日断続的に降らせる害験 (b) では, 常に葉に水 が付着するために蒸散量がゼロとなっており，また最も 遮断蒸発量が多かった. 流出量にも2 割程度の変化が みられた。降水強度に $\gamma$ 関数を経験的にあてはめて分配 した実験 (d) は (a) との対応が非常に良く, 地球規模の 水収支の算定に妥当な精度で応用可能であることが示 された。降水日数は観測值を用いているが, 降水強度は 月内の降水日に等分に与えた実験 (c) では, 遮断蒸発量 が (a)より多く, 流出量は減少した。このことから，降 水日数のみならず, $\gamma$ 法のような降水強度の適切な分配 も適切な水収支算定には必要であることがわかる.

\section{6. まとめ}

本研究では, 与えられる降雨の時間解像度に対する LSM の水文量 (蒸発散, 流出量) 算定の感度を, オフラ イン実験によって調べた．グローバル及びポイントの 解析によって，下記のような知見が得られた。

・グローバルにどの地点においても，降水を弱く継 続的に降らせることによって年間の遮断蒸発量が 増加し, 蒸散量は減少する. そのプラスマイナス の結果として, 総蒸発散量は増加し, 表面流出量 は減少する傾向にある。

・ LAI が大きい地点であるほど植生の遮断及び蒸散 の効果が大きく, 降水の時間解像度に対する LSM の感度は，ポテンシャルとしては大きくなる。し かし, 全体的な傾向はばらつく.

- 月降水量が $100 \mathrm{~mm}$ 前後の地点で降水の時間解像 度に対するLSM の感度は最も大きく, 月降水量 がそれよりも少ない又は多い地点での感度は低
い. $100 \mathrm{~mm}$ という数值は LAI 当たりの遮断能力 によって規定される数字である可能性も高く, モ デルによってある程度異なることも考えられる．

- $\gamma$ 関数によって月降水を日降水に配分する手法は, 観測降水量を与えた実験に非常に水収支が近く, グローバル水文量算定のためのダウンスケール手 法として実用に耐える妥当なものであることが示 された。

今回の実験では数カ月や年間の積算値について感度 の比較を行ったが, 今後水資源量としてこれら LSM の 出力值を解釈するためには月単位や日単位での水収支 の算定が量・タイミング共に適切に記述される必要が あるため，さらに細かい時間スケールにおけるLSM の 感度の入力降水量の時間スケールとの関連についても 調べていく必要があると思われる。

謝辞: 本研究は総合地球環境学研究所平成 14 年度プ ロジェクト「地球環境情報ライブラリと世界モデルを統 合した水危機管理システムの構築』(代表:沖 大幹) な らびに科学技術振興事業団 戦略的基礎研究推進事業 『人間活動を考慮した世界水循環水資源モデル』(代表:沖大 幹)の成果の一部である.ここに記して深く謝意を表します.

\section{参考文献}

1) P. Xie and P. A. Arkin. Global precipitation: A 17-year monthly analysis based on gauge observations, satellite estimates and numerical model outputs. Bull. Amer. Meteor. Soc., Vol. 78, pp. 2539-2558, 1997.

2) C. Prudhomme, N. Reynard, and S. Crooks. Downscaling of global climate models for flood frequency analysis: where are we now? Hydrological Processes, Vol. 16, pp. 1137-1150, 2002.

3) N. Sato and T. Nishimura. Global soil wetness projectsensitivity of a simulated water budget to temporal resolution of atmospheric forcings. GEWEX News, Vol. 5(2), pp. $1 \& 4-5,1995$.

4) P. J. Sellers, Y. Mintz, Y. C. Sud, and A. Dalcher. A simple biosphere model $(\mathrm{SiB})$ for use within general circulation models. J. Atmos. Sci., Vol. 43, No. 6, pp. 505-531, 1986.

5) N. Sato, K. Mabuchi, and P. J. Sellers. Simulation of snow deposition and melting by and offline simple biosphere model, 1999. submitted.

6) K. Takata and S. Emori. Development of the minimal advanced treatments of surface interaction and runoff. Global and Planetary Change, 2001. submitted.

7) P. J. Sellers, B. W. Meeson, J. Closs, J. Collatz, F. Corprew, D. Dazlich, F. G. Hall, Y. Kerr, R. Koster, S. Los, K. Mitchell, J. McManus, D. Myers, K.-J. Sun, and P. Try. ISLSCP Initiative I - Global Data Sets for LandAtmosphere Models, 1987-1988. CD-ROM by NASA, 1995.

8) G. E. Liston, Y. C. Sud, and G. Walker. Design of a global soil moisture initialization procedure for the simple biosphere model. NASA Tech. Memo., Vol. 104590, p. 130, 1993.

（2002. 9. 30受付） 